\title{
IDENTIFIKASI PERUBAHAN UNSUR-UNSUR IKLIM TERHADAP PRODUKTIFITAS PADI SAWAH DI KABUPATEN PIDIE JAYA
}

\author{
Junaidi $^{(1)}$, Hairul Basri ${ }^{(2)}$ dan Sugianto ${ }^{(3)}$ \\ ${ }^{1)}$ Magister Pertanian, Konservasi Sumberdaya Lahan, Fakultas Pertanian, Universitas Syiah Kuala \\ Jl. Tgk. Syeh Abdul Rauf No. 7, Darussalam Banda Aceh 23111, E-mail: junaidi.hasan81@yahoo.com \\ ${ }^{2,3)}$ Staf Pengajar Fakultas Pertanian, Universitas Syiah Kuala, Darussalam, Banda Aceh
}

\begin{abstract}
ABSTRAK
Penelitian bertujuan untuk menganalisis perubahan unsur-unsur iklim dan pergeseran musim tanam serta hubungannya terhadap produktifitas hasil tanaman padi secara spasial dalam kurun waktu 10 tahun di Kecamatan Bandar Baru, Bandar Dua dan Meureudu. Penelitian ini bersifat diskriptif yang dititik beratkan pada pengetahuan petani mengenai penerapan musim tanam dan adaptasi petani terhadap perubahan unsur-unsur iklim seperti curah hujan, kelembaban dan suhu wilayah yang dikaji adalah berdasarkan pengalaman petani terhadap permasalahan iklim yang dihadapi saat ini. Jenis data yang diambil adalah data sekunder dari BPP di Kecamatan Bandar Baru, Bandar Dua dan Meureudu dan dari Dinas Pertanian Kabupaten Pidie Jaya. Selanjutnya analisis data menggunakan regresi linier berganda, $\mathrm{Y}$ sebagai variabel terikat yaitu produksifitas padi (ton/ha) dan $\mathrm{X}$ sebagai variabel bebas yaitu unsur iklim yang berupa curah hujan $\left(\mathrm{X}_{1}\right)$, kelembaban $\left(\mathrm{X}_{2}\right)$, suhu $\left(\mathrm{X}_{3}\right)$ dan musim tanam $\left(\mathrm{X}_{4}\right)$. Hasil penelitian menunjukkan bahwa ratarata perubahan iklim di Kecamatan Bandar Baru, Bandar Dua dan Meureudu dalam kurun waktu 10 tahun dapat mempengaruhi hasil rata-rata produktifitas padi sebesar 6,55 ton/tahun dengan total rata-rata curah hujan adalah $1.942,30 \mathrm{~mm} / \mathrm{tahun}$, suhu sebesar $27,55{ }^{\circ} \mathrm{C}$ dengan penggolongan panas dan kelembaban sebesar 78,23\% dengan indek kelembaban basah berdasarkan klasifikasi Douglas H.K. Lee. Rata-rata pergeseran musim tanam gaduh di Kecamatan Bandar Baru selama 22 hari, Bandar Dua selama 20 hari dan meureudu selama 19 hari, akan tetapi terjadi pergeseran rata-rata musim tanam rendengan di Kecamatan Bandar Baru selama 19 hari, Bandar Dua selama 17 hari dan Meureudu selama 18 hari dan berhubungan negatif yang nyata antara pergeseran musim tanam dan perubahan iklim, sehingga tingkat produktifitas padi terjadi penurunan di Kecamatan di Bandar Baru, Bandar Dua dan meureudu dengan nilai koefisien determinasi masing-masing sebesar 46,82 persen, 54,47 persen dan 21,83 persen
\end{abstract}

Kata kunci: unsur-unsur iklim, musim tanam, produktifitas padi.

\begin{abstract}
Research aims to analyze the changes elements climate and so shift of the growing season and relation to productivity from the sale of rice in spatial in the decade of doing in Bandar Baru, Bandar dua dan Meureudu Sub-district. This research is diskriptif in focus on on knowledge farmers regarding the application of of the growing season and adaptation farmers on changes in climate elements of rainfall, the humidity and temperature of areas of the study is based on the experience farmers climate of the problems faced by now. The kind of data that taken is secondary data from BPP in Bandar Baru, Bandar dua dan Meureudu Sub-district and from Department of Agriculture Pidie Jaya District. Next analysis data using linear regression multiple, $\mathrm{Y}$ as variable bound namely rice productivity (ton/ha) and $\mathrm{X}$ as a variable free the climate element of rainfall $\left(\mathrm{X}_{1}\right)$, moisture $\left(\mathrm{X}_{2}\right)$, temperature $\left(\mathrm{X}_{3}\right)$ and the growing season $\left(\mathrm{X}_{4}\right)$.
\end{abstract}


The research results show that average climate change in Bandar Baru, Bandar dua dan Meureudu Sub-district in the decade of doing can affect the average yield rice productivity of 6,55 tons/year with the total average rainfall is $1.942,30 \mathrm{~mm} /$ year, temperature of $27,55{ }^{0} \mathrm{C}$ network with of the heat and moisture of 78,23\% with index moisture wet based on classifications Douglas H.K. Lee. Average shift of the growing season rowdy in Bandar Baru Sub-district for 22 days, Bandar Dua for 20 days and Meureudu for 19 days, will but occurs shift the average of the growing season in Bandar Baru Sub-district for 19 days, Bandar Dua for 17 days and Meureudu for 18 days and have negative real between shift of the growing season and climate change, so that the rate productivity rice a decline in Bandar Baru, Bandar Dua and Meureudu Sub-district, with the determination of the coefficients each 46,82 percent, 54,47 percent and 21,83 percent

Keywords: climate elements, the growing season, rice productivity

\section{PENDAHULUAN}

Perubahan unsur iklim adalah penyebab utama kekeringan diseluruh dunia. Penelitian meteorologi melalui informasi satelit dan riwayat iklim dapat mengurangi dampak kekeringan. Dengan kesadaran yang tepat, korban kekeringan dapat berlatih terhadap berbagai penyesuaian untuk mengatasi kekeringan (Miyan, 2014 dalam Basri et al. 2015). Kekeringan berhubungan dengan ketersediaan air di alam terhadap kebutuhan hidup manusia dan lingkungan. Kekeringan di beberapa wilayah Indonesia kini menjadi permasalahan yang cukup mengkhawatirkan. Hampir rata-rata setiap tahunnya sebagian wilayah indonesia mengalami bencana tersebut (Surtarja, 2013) Fenomena perubahan iklim di Kabupaten Pidie Jaya, Propinsi Aceh menjadi salah satu wilayah yang memerlukan penangganan. Fakta yang kita jumpai adalah ratusan hektar sawah Kecamatan Bandar Baru, Bandar Dua dan Meureudu Kabupaten Pidie Jaya mengalami kekeringan akibat aliran sungai terbatas.

Pemantauan dan prediksi kekeringan telah dilakukan dengan berbagai metode. Secara meteorologis, kekeringan dapat diprediksi dan dipantau berdasarkan data cuaca dari stasiun meteorologi. Selain itu, perkembangan teknologi satelit memungkinkan fenomena cuaca dan iklim dapat dipelajari dan dideteksi secara komprehensif untuk wilayah yang luas. Pemanfaatan data penginderaan jauh satelit untuk mendeteksi dan memetakan kekeringan telah dilakukan sejak tahun 1980-an. Data satelit lingkungan dan cuaca yang tersedia pada saat itu, memungkinkan untuk mendeteksi gejala-gejala alam yang berkaitan dengan kekeringan. Diawali dengan analisis awan dari citra satelit untuk mempelajari fenomena cuaca, kemudian dikembangkan analisis suhu permukaan laut global untuk mengetahui anomali iklim (Adiningsih, 2014).

Kajian pergeseran tanam ini secara morfologi tanaman dapat diketahui dengan melakukan monitoring secara rutin setiap tahun. Kegiatan ini sangat menyita waktu dan jika waktunya sudah berlalu akan sulit untuk menentukannya. Salah satu cara untuk memonitor perubahan ini meskipun waktunya sudah berlalu adalah dengan pemanfaatan citra satelit. Penggunaan citra satelit untuk memonitor perubahan tutupan lahan oleh beberapa peneliti antara lain Amarsaikhan et al, (2009), Brooker et al., (2013), untuk stress tanaman (Ren et. al, 2003) dan spesies tanaman (Prospere, et al, 2014, Liu et al. 2009). Khusus untuk tanaman padi, Mostafa, et al. (2014) memanfaatkan citra satelit untuk memonitor produktifitas padi.

Berdasarkan data yang diperoleh dari Badan Pusat Statistik (BPS), prioritas utama masyarakat tani di Kecamatan Bandar baru, Bandar dua dan Meureudu adalah pada subsektor tanaman pangan yaitu padi sawah. Hal ini disebabkan karena kondisi lahan yang sangat mendukung untuk komoditi 
tersebut. Data terakhir pada Dinas Pertanian dan Pangan (Distanpang) Pidie Jaya (2017), menunjukkan bahwa produksi padi di kabupaten ini dari tahun ke tahun terus meningkat. Tahun 2014 dari produksi padi petani sekitar 64.912 ton, tahun 2015 meningkat menjadi 94.651 ton dan pada tahun 2017, produksinya mencapai 100.319 ton. Tahun 2016 memang ada penurunan sedikit, akibat kondisi alam (cuaca) yang kurang mendukung, termasuk terjadinya bencana alam gempa di akhir tahun, sehingga produksinya 93.147 ton. Tapi tahun 2017, produksi padi petani bisa ditingkatkan kembali.

\section{BAHAN DAN METODE PENELITIAN}

Penelitian ini dilaksanakan pada bulan Maret sampai bulan Juli 2018 di Tiga (3) Kecamatan Kabupaten Pidie Jaya yang dapat diakses data spasial, yaitu Kecamatan Bandar Baru, Bandar Dua dan Meureudu.

Penelitian ini bersifat diskriptif yang dititik beratkan pada pengetahuan petani mengenai penerapan musim tanam dan adaptasi petani terhadap perubahan unsurunsur iklim seperti curah hujan, kelembaban dan suhu wilayah yang dikaji adalah berdasarkan pengalaman petani terhadap permasalahan iklim yang dihadapi saat ini. Jenis data yang diambil adalah data sekunder dari BPP di Kecamatan Bandar Baru, Bandar Dua dan Meureudu dan dari Dinas Pertanian Kabupaten Pidie Jaya. Selanjutnya analisis data menggunakan regresi linier berganda, Y sebagai variabel terikat yaitu produksifitas padi (ton/ha) dan $\mathrm{X}$ sebagai variabel bebas yaitu unsur iklim yang berupa curah hujan $\left(\mathrm{X}_{1}\right)$, kelembaban $\left(\mathrm{X}_{2}\right)$, suhu $\left(\mathrm{X}_{3}\right)$ dan musim tanam $\left(\mathrm{X}_{4}\right)$.

Tahap awal pada penelitian ini adalah melakukan pengumpulan data yang mempengaruhi produktifitas padi sawah di Kabupaten Pidie Jaya seperti data iklim dan data produktifitas padi sawah serta tahapan pelaksanaan dalam penelitian adalah tahap persiapan meliputi studi kepustakaan, yaitu pengumpulan informasi awal yang berkaitan dengan studi, pembuatan proposal yang berisi arahan kegiatan yang dilakukan, pembuatan daftar data dan instansi sehingga memudahkan pengumpulan data di lapangan. Pengumpulan data adalah untuk mengumpulkan data sekunder, seperti data iklim, suhu udara, kelembaban udara, hasil produktifitas padi, luas lahan tanam dan luas lahan panen di Kabupaten Pidie Jaya.

Evaluasi dan penyempurnaan data terdiri dari pengecekkan dan evaluasi data yang telah dikumpulkan, serta penyempurnaan kelengkapan data. Analisis data dilakukan baik secara manual maupun bantuan komputer yang meliputi pengelompokkan data, analisis karakteristik iklim, perubahan unsur iklim wilayah dan analisis dampak dari perubahan iklim terhadap produktifitas dan luas lahan panen pada musim tanam padi sawah di Kabupaten Pidie Jaya, kemudian menghitung data curah hujan yang didapatkan dari BMKG dari tahun 2008 sampai tahun 2017. Analisa buffer digunakan untuk mengidentifikasi area sekitar fitur-fitur geografi. Proses mengenerate sekitar lingkaran buffer yang ada fitur-fitur geografi dan kemudian mengidentifikasi atau memilih fitur-fitur berdasarkan pada apakah mereka berada di luar atau didalam batas buffer. Dengan membuat buffer, maka akan terbentuk suatu area, polygon, atau zone baru yang menutupi (atau melingkupi) objek spasial (buffered object) yang berupa objek-objek titik, garis atau area (polygon tertentu) dengan jarak batas penelitian.

\section{HASIL DAN PEMBAHASAN \\ Perubahan Unsur Iklim di Kabupaten Pidie Jaya}

Perubahan unsur iklim terjadi disebabkan oleh rotasi dan revolusi bumi serta adanya perbedaan garis lintang berdasarkan intensitas curah hujan dengan membandingkan antara bulan basah $(<60$ $\mathrm{mm}$ ) dengan bulan kering (> $60 \mathrm{~mm}$ ). Adapun indikasi yang terjadi dalam perubahan unsur iklim di Kecamatan Bandar Baru, Bandar Dua dan Meureudu dapat dilihat pada rata-rata intensitas curah hujan, suhu dan kelembaban udara. 


\section{Rata-rata Curah Hujan Wilayah}

Berdasarkan hasil analisis rata-rata curah hujan di Kecamatan Bandar Baru, Bandar Dua dan Meureudu dengan total rata-rata curah hujan dalam kurun waktu 10 tahun adalah 1.942,30 mm/tahun dapat di lihat pada Tabel 1.

Tabel 1. Total rata-rata curah hujan dalam kurun waktu 10 tahun di Kecamatan Bandar Baru, Bandar Dua dan Meureudu

\begin{tabular}{cc}
\hline Periode Tahun & $\begin{array}{c}\text { Rata-rata curah hujan } \\
(\text { mm/tahun })\end{array}$ \\
\cline { 2 - 2 } 2008 & 2.353 \\
2009 & 2.167 \\
2010 & 2.539 \\
2011 & 1.506 \\
2012 & 1.715 \\
2014 & 1.741 \\
2015 & 1.412 \\
2016 & 1.633 \\
2017 & 2.059 \\
Rata-rata total & 2.298 \\
\hline
\end{tabular}

Sumber data : BPP Kecamatan Bandar Baru, Bandar Dua dan Meureudu

Tabel 1. dapat dijelaskan bahwa ratarata curah hujan tertinggi adalah pada Tahun 2010 sebesar $2.539 \mathrm{~mm} /$ tahun dan terendah pada Tahun 2014 adalah sebesar 1.412 $\mathrm{mm} /$ tahun dan terjadi peningkatan curah hujan pada Tahun 2017 sebesar 2.298 $\mathrm{mm} / \mathrm{tahun}$. Hal ini diduga disebabkan oleh ketidakteraturan musim pada saat ini merupakan imbas dari penyebab perubahan iklim. Pada musim penghujan, sawah tadah hujan mendapat dampak positif saat pengairan, akan tetapi hama penyakit pada saat penghujan meningkat. Kemudian untuk musim kemarau, petani sawah tadah hujan harus menggunakan adaptasi dengan menggunakan teknologi yaitu berupa pompa air bawah tanah agar pengairan berjalan dengan optimal. Akan tetapi penggunaan teknologi tersebut hanya dapat dinikmati oleh petani kelas atas karena biaya penyewaan atau pembelian alat tersebut relatif mahal.

Ritchie (1972) menyatakan bahwa tingkat ketersediaan air bagi suatu pertanaman berpengaruh pada proses pembukaan stomata dan laju fotosintesis. Salah satu indikator dari proses ini adalah laju transpirasi tanaman, sehingga jika air tersedia cukup untuk proses transpirasi maka laju fotosintesis akan berlangsung dengan optimal dan sebaliknya, jika air tidak tersedia terus menerus maka tanaman akan mengalami cekaman (stress) air sehingga menjadi kering dan akhirnya mati, sehingga akan mengurangi luas panen suatu pertanaman padi.

\section{Suhu Udara}

Hasil analisis suhu udara dengan menggunakan Klasifikasi Douglas H.K. Lee. Berdasarkan hasil analisis bahwa suhu rata-rata pada kurun waktu 10 Tahun (Tahun 2008 s/d Tahun 2017) adalah sebesar 27,55 ${ }^{0} \mathrm{C} /$ tahun yang digolongkan panas, Menurut klasifikasi Klasifikasi Douglas H.K. Lee suhu rata-rata di Kabupaten Pidie Jaya masih tetap berada diantara $68^{0}-86^{0} \mathrm{~F}\left(20^{0}-30^{\circ} \mathrm{C}\right)$ panas selama 10 tahun terakhir dapat dilihat pada Tabel 2.

Tabel 2. Total rata-rata suhu dalam kurun waktu 10 tahun di Kecamatan Bandar Baru, Bandar Dua dan Meureudu

\begin{tabular}{cc}
\hline Periode Tahun & Rata-rata suhu $\left({ }^{\circ} \mathrm{C}\right)$ \\
\hline 2008 & 27,98 \\
2009 & 27,50 \\
2010 & 27,45 \\
2011 & 27,98 \\
2012 & 27,35 \\
2013 & 27,40 \\
2014 & 27,90 \\
2015 & 27,00 \\
2016 & 27,33 \\
2017 & 27,59 \\
\hline Rata-rata total & 27,55 \\
\hline
\end{tabular}

Sumber data: BPP Kecamatan Bandar Baru, Bandar Dua dan Meureudu

Pada Tabel 2 dapat dijelaskan bahwa rata-rata suhu tertinggi di jumpai pada Tahun 2008 dan Tahun 2011 sebesar 27,98 ${ }^{0} \mathrm{C}$ dan rata-rata suhu terendah dijumpai 
pada Tahun 2015 sebesar $27{ }^{0} \mathrm{C}$ dan terjadi penurunan suhu pada Tahun 2017 sebesar $27,59{ }^{\circ} \mathrm{C}$ atau $0,16 \%$. Kabupaten Pidie Jaya mengalami kenaikan suhu rata-rata selama 1 tahun terakhir sebesar $0,3{ }^{0} \mathrm{C}$ sampai $0,5{ }^{0} \mathrm{C}$. Menurut rusbiantoro (2008) adapun dampak dari kenaikan ini belum berakibat fatal karena masih dibawah rata-rata. Apabila perubahan kenaikan ini tidak bisa diatasi maka ancaman kedepan akan semakin dirasakan. Peningkatan suhu rata-rata global sejak pertengahan abad ke-20 menurut Intergovernmental Panel on Climate Change (IPCC) sebagian besar disebabkan oleh meningkatnya konsentrasi gas-gas rumah kaca akibat aktivitas manusia. Suhu permukaan global akan meningkat $1,1^{\circ} \mathrm{C}$ hingga $6,4^{\circ} \mathrm{C}$ antara tahun 1990 dan 2010.

Dengan menggunakan model iklim, perbedaan angka perkiraan itu disebabkan oleh penggunaan skenario-skenario berbeda mengenai emisi gas-gas rumah kaca di masa mendatang, serta model-model sensitivitas iklim yang berbeda. Walaupun sebagian besar penelitian terfokus pada periode hingga Tahun 2010, pemanasan dan kenaikan muka air laut diperkirakan akan terus berlanjut selama lebih dari seribu tahun walaupun tingkat emisi gas rumah kaca telah stabil. Ini mencerminkan besarnya kapasitas panas dari lautan.

\section{Kelembaban}

Kelembaban diuji $\begin{array}{r}\text { dengan } \\ \text { Klasifikasi }\end{array}$
Douglas H.K. Lee, rata-rata kelembaban
udara dalam kurun waktu dari Tahun 2008
sampai dengan Tahun 2017 sekitar $78.23 \%$
(dengan pengolongan B yaitu basah), Hal ini
memberikan informasi bahwa kelembaban
udara di Kabupaten Pidie Jaya menurun
sekitar 0,38\% dari Tahun 2008 terakhir.
Namun untuk penelitian ini belum bisa
merubah kelas kelembaban udara karena
masing tergolong basah. Selanjutnya
perubahan kelembaban di Kecamatan
Bandar Baru, Bandar Dua dan Meureudu
dapat dilihat pada Tabel 3.

Tabel 3. Total rata-rata kelembaban dalam kurun waktu 10 tahun di Kecamatan Bandar Baru, Bandar Dua dan Meureudu

\begin{tabular}{cc}
\hline Periode Tahun & Rata-rata kelembaban $(\%)$ \\
\hline 2008 & 79,40 \\
2009 & 77,00 \\
2010 & 78,00 \\
2011 & 78,50 \\
2012 & 78,40 \\
2013 & 78,80 \\
2014 & 76,80 \\
2015 & 77,90 \\
2016 & 79,00 \\
2017 & 78,50 \\
\hline Rata-rata total & \\
\hline
\end{tabular}

Pada Tabel 3 dapat dijelaskan bahwa rata-rata kelembaban tertinggi di jumpai pada Tahun 2008 sebesar 79,4\% dan kelembaban suhu terendah dijumpai pada Tahun 2014 sebesar 76,80\%. Menurut metode Mohr dalam Bayong (2004), bahwa ada 3 pembagian derajat kelembaban : (1) jika jumlah curah hujan dalam 1 bulan lebih dari $100 \mathrm{~mm}$ maka bulan ini dinamakan bulan basah, jumlah curah hujan melampaui jumlah penguapan. (2) jika jumlah curah hujan dalam 1 bulan kurang dari $60 \mathrm{~mm}$, maka bulan ini dinamakan bulan kering, karena penguapannya banyak berasal dari air dalam tanah daripada curah hujan. (3) jika jumlah hujan dalam 1 bulan antara 60 $100 \mathrm{~mm}$ maka bulan ini dinamakan bulan lembab, karena curah hujan dan penguapan hampir seimbang. Menurut Mohr kenaikan ini tergolong normal dan seimbang, karena jumlah curah hujan yang diperoleh pada tiga Kecamatan kisaran antara $60 \mathrm{~mm}$ - 100 $\mathrm{mm}$

setiap bulannya. Sehingga pada Tahun 2017 tersebut tergolong agak lembab karena terjadinya penurunan jumlah hujan, serta pada 10 Tahun sebelumnya tergolong tidak normal karena terjadi hujan yang tinggi, hal ini terlihat pada jumlah hujan bulanan.

\section{Pergeseran Musim Tanam}

Berdasarkan hasil analisis dari ratarata pergeseran musim tanam di Kecamatan Bandar Baru, Bandar Dua dan Meureudu 
pada Tahun 2008 sampai Tahun 2017 dapat di lihat pada Gambar 1.

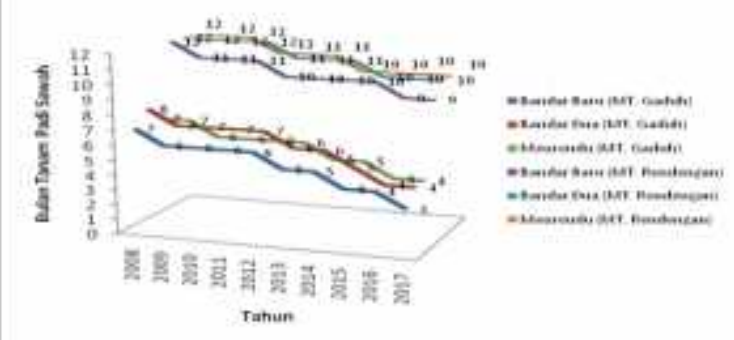

Gambar 1. Pergeseran musim tanam mewakili masing-masing Kecamatan Bandar Baru, Bandar Dua dan Meureudu (Tahun 2008-2017)

Gambar 1 dapat dijelaskan bahwa musim tanam gaduh di Kecamatan Bandar Baru pada Tahun 2008 dimulai dari Bulan Juli sampai Bulan Agustus (Lampiran 2) dengan lama musim tanam selama 21 hari, namun terjadi pergeseran musim tanam selama 11 hari pada Tahun 2009 dengan awal musim tanam dari bulan Juni sampai Bulan Juli sampai Tahun 2012 dengan ratarata jumlah 17 sampai 28 hari, namun pada Tahun 2013, Tahun 2015 dan sampai dengan Tahun 2017 kembali terjadi pergeseran musim tanam dalam rentang waktu selama 28 dan 20 hari berturut-turut dengan jumlah awal musim tanam rata-rata 15 sampai 31 hari. Akan tetapi pada musim tanam rendengan dimulai pada Bulan Desember Tahun 2008 yaitu selama 26 hari, namun terjadi pergeseran musim tanam selama 9 hari pada Tahun 2009 dengan awal musim tanam yaitu tetap pada Bulan November sampai Bulan Desember Tahun 2011 dengan jumlah rata-rata 17 sampai 23 hari. Tahun 2012 juga terjadi pergeseran musim tanam selama 13 hari yaitu mulai pada Bulan Oktober Tahun 2015 dengan jumlah rata-rata 8 sampai 19 hari dan kembali terjadi pergeseran selama 8 hari pada Tahun 2016 pada Bulan September Tahun 2017 selama rentang 21 sampai 26 hari.

Musim tanam gaduh di Kecamatan Bandar Dua yaitu pada Bulan Agustus
Tahun 2008 yaitu selama 18 hari dan terjadi pergeseran musim tanam selama 12 hari pada Tahun 2009 yaitu pada Bulan Juli sampai Tahun 2012 dengan jumlah rata-rata 17 sampai 23 hari, Tahun 2013 sampai Tahun 2014 tetap pada Bulan Juni dengan rata-rata 17 sampai 25 hari serta pada Bulan Mei Tahun 2015 terjadi pergeseran musim tanam selama 11 hari sampai Tahun 2016, Tahun 2017 kembali terjadi pergeseran 50 hari yaitu pada Bulan April dengan jumlah rata-rata selama 12 sampai 25 hari. Akan tetapi pada musim tanam rendengan Tahun 2008 sampai Tahun 2011 yaitu jumlah ratarata hari penanaman selama 10 sampai 26 hari, namun terjadi pergeseran musim tanam selama 6 hari pada Tahun 2012 awal musim tanam yaitu pada Bulan November sampai Tahun 2014 dengan jumlah rata-rata 8 sampai 14 hari dan pada Tahun 2015 juga terjadi pergeseran musim tanam selama 38 hari yaitu pada Bulan Oktober Tahun 2017 dengan jumlah rata-rata 22 sampai 28 hari.

Musim tanam gaduh di Kecamatan Meureudu pada Tahun 2008 sampai Tahun 2009 pada Bulan Juli yaitu selama 19 hari dan terjadi pergeseran musim tanam selama 40 hari pada Tahun 2010 yaitu pada Bulan Juni Tahun 2013 dengan jumlah rata-rata 13 sampai 26 hari, namun pada Tahun 2014 dan 2016 kembali terjadi pergeseran musim tanam dalam rentang waktu selama 13 dan 20 hari sampai dengan Bulan April Tahun 2017 berturut-turut dengan jumlah rata-rata 10 sampai 26 hari. Akan tetapi pada musim tanam rendengan Tahun 2008 sampai Tahun 2010 yaitu rata-rata selama 13 sampai 26 hari, namun terjadi pergeseran musim tanam selama 10 hari pada Tahun 2011 dengan awal musim tanam yaitu pada Bulan November Tahun 2013 dengan jumlah ratarata 17 sampai 19 hari dan pada Tahun 2014 juga terjadi pergeseran musim tanam selama 5 hari yaitu mulai pada Bulan Oktober Tahun 2017 dengan jumlah rata-rata hari penanaman selama 9 sampai 24 hari.

Pergeseran Musim tanam yang terjadi diduga disebabkan keragaman pola curah hujan, baik tahunan maupun bulanan antar 
Kecamatan Bandar Baru, Bandar Dua dan Meureudu terjadi perbedaan curah hujan yang tidak begitu besar. Menurut Hermawan (2010) pada bulan Januari pergerakan semu matahari berada $23,5^{\circ}$ di Belahan Bumi Selatan (BBS), sehingga bertiup angin dari utara menuju selatan yang lebih dikenal dengan Monsun Barat. Kemudian pada bulan Agustus berlaku sebaliknya, terjadi pergerakan masa udara dari Selatan menuju Utara yang lebih dikenal dengan Monsun Timur, sedangkan pada bulan-bulan lainnya diistilahkan dengan musim peralihan

Pengaruh Perubahan Musim Tanam terhadap Produktifitas Padi Sawah dan Luas Lahan Panen dalam kurun waktu 10 Tahun

\section{Luas Lahan Panen}

Luas lahan panen pada Tahun 2008 di Kecamatan Bandar Baru, Bandar Dua dan Meureudu berdasarkan hasil data (Pidie Jaya dalam Angka) masing-masing hamparan dengan luas 1.980 ha, 3.150 ha dan 1.850 ha, akan tetapi pada tahun 2017 terjadi pertambahan luas lahan panen di Kecamatan Meuereudu seluas 2.333 ha, di Kecamatan Bandar Dua seluas 2.886 ha dan Kecamatan Bandar Baru seluas 4.569 ha dapat di lihat pada Tabel 4.

Tabel 4. Total rata-rata luas lahan panen dalam kurun waktu 10 tahun di Kecamatan Bandar Baru, Bandar Dua dan Meureudu

\begin{tabular}{llcl} 
& \multicolumn{3}{c}{ Kecamatan } \\
\cline { 2 - 4 } Tahun & $\begin{array}{c}\text { Bandar } \\
\text { Baru }\end{array}$ & $\begin{array}{c}\text { Bandar } \\
\text { Dua }\end{array}$ & Meureudu \\
\cline { 2 - 4 } & & $\cdots$. Ha & \\
\hline 2008 & & $\cdots$. & 1.850 \\
2009 & 1.980 & 3.150 & 1.850 \\
2010 & 1.980 & 3.150 & 1.980 \\
2011 & 1.995 & 3.194 & 1.065 \\
2012 & 2.065 & 2.928 & 1.970 \\
2013 & 2.200 & 2.707 & 1.656 \\
2014 & 2.614 & 3.728 & 1.089 \\
2015 & 2.135 & 2.945 & 2.265 \\
2016 & 2.395 & 4.914 & 2.302 \\
2017 & 2.770 & 4.567 & 2.333 \\
\hline
\end{tabular}

Sumber data : BPP Kecamatan Bandar Baru, Bandar dua dan Meureudu

Berdasarkan hasil analisis pada Tabel 4 menunjukkan bahwa luas rata-rata area lahan di Kecamatan Bandar Baru terjadi pertambahan luas area pada Tahun 2017 dengan luas 2.886 ha dari Tahun 2008 dan di Kecamatan Banda Dua Tahun 2015 bertambah 4.914 ha dari 2.707 ha pada Tahun 2012 akan tetapi di Kecamatan Meureudu pada Tahun 2017 bertambah dengan luas 2.333 ha dari Tahun 2011 dengan luas 1.065 ha. Hal ini dapat disimpulkan bahwa Kabupaten Pidie Jaya diduga terjadi alih fungsi lahan pertanian menjadi lahan non pertanian sehingga dampak dari perubahan iklim berpengaruh negatif terhadap produktifitas padi sawah.

\section{Produktifitastifitas Padi Sawah di Kecamatan Bandar Baru, Bandar Dua dan Meureudu}

Rata-rata produktifitas padi sawah dari kurun waktu Tahun 2008 sampai Tahun 2017 di Kecamatan Bandar Baru, Bandar Dua dan meureudu masing-masing mencapai 6,52 ton/ha, 6,55 ton/ha dan 6,88 ton/ha. Hasil produktifitas di Kecamatan Bandar Baru, Bandar Dua dan meureudu dapat dilihat pada Tabel 5.

Tabel 5. Total rata-rata produktifitas dalam kurun waktu 10 tahun di Kecamatan Bandar Baru, Bandar Dua dan Meureudu.

\begin{tabular}{lccc}
\hline & \multicolumn{3}{c}{ Kecamatan } \\
\cline { 2 - 3 } Tahun & $\begin{array}{c}\text { Bandar } \\
\text { Baru }\end{array}$ & $\begin{array}{c}\text { Bandar } \\
\text { Dua }\end{array}$ & \multicolumn{2}{c}{ Meureudu } \\
\cline { 2 - 3 } 2008 & 6,15 & 6,39 & 6,16 \\
2009 & 6,15 & 6,39 & 6,16 \\
2010 & 6,03 & 6,27 & 7,25 \\
2011 & 7,49 & 7,38 & 7,65 \\
2012 & 7,25 & 8,10 & 8,70 \\
2013 & 8,12 & 7,98 & 8,76 \\
2014 & 5,82 & 5,82 & 5,92 \\
2015 & 6,43 & 5,46 & 6,34 \\
2016 & 5,92 & 5,76 & 5,74
\end{tabular}




\begin{tabular}{cccc}
2017 & 5,82 & 5,94 & 6,13 \\
\hline $\begin{array}{c}\text { Rata-rata } \\
\text { total }\end{array}$ & 6,52 & 6,55 & 6,88 \\
\hline
\end{tabular}

$\overline{\text { Sumber data : BPP Kecamatan Bandar Baru, }}$ Bandar dua dan Meureudu

Berdasarkan hasil analisis Tabel 5 menunjukkan bahwa terjadi peningkatan produktifitas hasil tanaman padi di Kecamatan Bandar Baru, Bandar Dua dan meureudu dari Tahun 2011 sampai Tahun 2013, namun pada Tahun 2014 sampai Tahun 2017 tingkat hasil produktifitasfitas tanaman padi kembali terjadi penurunan. Hal ini diduga disebabkan oleh faktor lingkungan (hama dan penyakit) serta perubahan iklim dan cuaca juga merupakan faktor yang sangat penting dalam menentukan tingkat keberhasilan produktifitas pertanian khususnya tanaman padi dan kekeringan merupakan masalah utama bertani didaerah tropis termasuk di Indonesia. Daerah tropis seperti Indonesia secara umum tidak semua unsur iklim dan cuaca berpengaruh kuat terhadap petumbuhan dan perkembangan tanaman.

\section{Hubungan Pergeseran Musim Tanam dan Perubahan iklim terhadap Produktifitas Padi}

Berdasarkan hasil analisis regresi linier berganda dengan metode analisis toolpak microsoft excell, antara pengaruh pergeseran musim tanam dan perubahan iklim terhadap produktifitas padi di Kecamatan Bandar Baru, Bandar Dua dan Meureudu diperoleh koefisien-koefisien persamaan matematis yang membentuk model seperti ditunjukkan dalam Gambar 2.

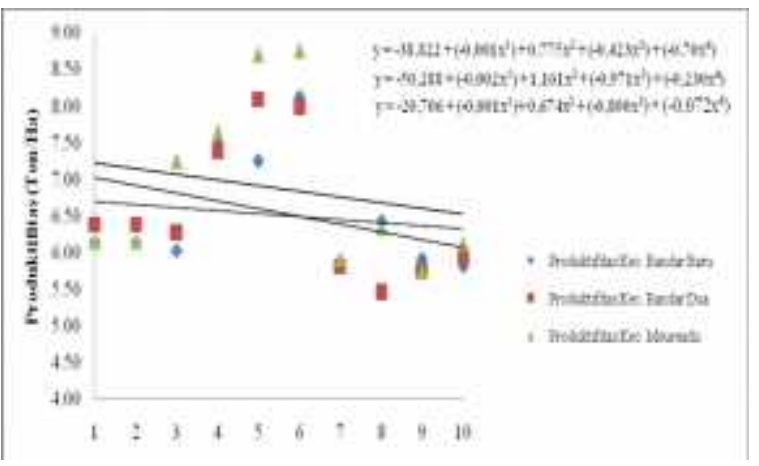

Gambar 2. Grafik hubungan hasil analisis regresi rata-rata produktifitas padi yang mewakili masing-masing Kecamatan Bandar Baru, Bandar Dua dan Meureudu dalam kurun 10 tahun (2008-2017).

Model regresi yang dipakai (Gambar

2) berdasarkan hasil analisis pada Kecamatan Bandar Baru adalah dengan model $y=-38,822+\left(-0,001 x^{1}\right)+0,775 x^{2}+$ $\left(-0,423 x^{3}\right)+\left(-0,70 x^{4}\right)$, Kecamatan Bandar Dua adalah dengan model $\mathrm{y}=-50,288+(-$ $\left.0,002 x^{1}\right)+1,161 x^{2}+\left(-0,971 x^{3}\right)+\left(-0,230 x^{4}\right)$ dan Kecamatan Meureudu dengan model y $=-20,706+\left(-0,001 x^{1}\right)+0,674 x^{2}+(-$ $\left.0,800 \mathrm{x}^{3}\right)+\left(-0,072 \mathrm{x}^{4}\right)$. Berdasarkan hasi uji anova terjadi pengaruh hubungan negatif yang nyata antara pergeseran musim tanam dan perubahan iklim, sehingga semakin cepat terjadi perubahan iklim dan pergeseran musim tanam di Kecamatan Bandar Baru, Bandar dua dan Meureudu masing-masing dengan nilai koefisien determinasi $\left(\mathrm{R}^{2}\right)$ sebesar 46,82 persen, 54,47 persen dan 21,83 persen.

Hal ini diduga terjadi oleh pengaruh iklim dan ketersediaan air secara serempak adalah signifikan terhadap produktifitas padi. Perubahan ketersediaan air akibat pergeseran musim, penurunan intensitas hujan serta kenaikan suhu tentunya memiliki pengaruh bagi pertanian padi yang dalam budidayanya sangat bergantung pada ketersediaan air di Kecamatan Bandar Baru, Bandar dua dan Meureudu. Namun pengaruh yang dirasakan tidak sama antara padi sawah irigasi dengan padi padi sawah tadah hujan. Sawah tadah hujan memiliki tingkat kerentanan yang lebih tinggi akibat perubahan ketersediaan air dibandingkan dengan sawah irigasi. Pada sawah tadah hujan, perubahan ketersediaan air menjadi hal yang sangat berpengaruh pada pertanian padi di wilayah ini. Perubahan ketersediaan air yang menunjukkan kecenderungan penurunan ketersediaan air dikarenakan datangnya musim hujan semakin tidak pada waktunya, serta intensitas hujan yang menurun pula. 


\section{KESIMPULAN DAN SARAN \\ Kesimpulan}

1. Rata-rata perubahan iklim di Kecamatan Bandar Baru, Bandar Dua dan Meureudu dapat mempengaruhi hasil produktifitas padi dengan total rata-rata curah hujan dalam kurun waktu 10 tahun adalah $1.942,30 \mathrm{~mm} / \mathrm{tahun}$, suhu sebesar 27,55 ${ }^{\circ} \mathrm{C}$ dengan penggolongan panas dan kelembaban sebesar 78,23\% dengan indek kelembaban basah berdasarkan klasifikasi Douglas H.K. Lee.

2. Rata-rata pergeseran musim tanam gaduh di Kecamatan Bandar Baru selama 22 hari, Bandar Dua selama 20 hari dan meureudu selama 19 hari, akan tetapi terjadi pergeseran rata-rata musim tanam rendengan di Kecamatan Bandar Baru selama 19 hari, Bandar Dua selama 17 hari dan meureudu selama 18 hari

3. Terjadi hubungan negatif yang nyata antara pergeseran musim tanam dan perubahan iklim, sehingga tingkat produktifitas padi terjadi penurunan di Kecamatan di Bandar Baru, Bandar Dua dan meureudu dengan nilai koefisien determinasi $\left(\mathrm{R}^{2}\right)$ masing-masing sebesar 46,82 persen, 54,47 persen dan 21,83 persen

\section{Saran}

Diharapkan kepada pemerintah daerah Kabupaten Pidie Jaya perlu adanya informasi tentang perubahan iklim dan musim tanam terhadap hasil produktifitas tanaman padi sawah, agar dapat dipublikasikan secara kontinue melalui media cetak maupun media elektronik kepada petani.

\section{DAFTAR PUSTAKA}

Adiningsih 2014. Tinjauan Metode Deteksi Parameter Kekeringan Berbasis Data Pengindraan Jauh. Proseding Seminar Nasional Pengundraan Jauh.
Agus et al. 2002. Informasi Singkat Benih Altingia excelca Noronha. Bandung:

Amarsaikhan, D., Blotevoge, $\mathrm{H} \quad \mathrm{H}$., Ganzorig, M., Moon, H T., 2009. Applications of remote sensing and geographic information systems for urban land-cover change studies in Mongolia. Geocarto International Vol. 24, 257- 271.

Anonim.2009. Teori Dasar Interpretasi Citra Satelit Lansat TM7+ Metode Interpretasi Visual (Digitaze Screen). (Online), http: //www. oocities.org/ yaslinus /citra.html. Di akses tanggal 28 Maret 2015.

Arafah. 2009. Pedoman Teknis Perbaikan Kesuburan Lahan Sawah Berbasis Jerami. Jakarta : PT. Gramedia. $238 \mathrm{hlm}$.

Arafah. 2010. Pengelolaan dan Pemanfaatan Padi Sawah. Bogor : Bumi Aksara. $428 \mathrm{hlm}$.

Bayong, T.H.K., 2004. Klimatologi, Penerbit ITB, Bandung

BMKG, 2011， Perubahan Iklim dan Dampaknya di Indonesia. (Internet) (Diakses 12 Maret 2017)

Boer, R and Meinke, H. 2002. Plant Growth and the SOI, in Will It Rain? The effect of the Southern Oscillatioon and El Nino in Indonesia. Department of Primary Industries Queensland, Brisbane Australia.

Brooker, R.W., Matesanz, S., Valladares, F., Stefan Klotz, S., 2013. Long-term spatial pattern change in a semiarid plant community: The role of climate and composition. Acta Oecologica 45, 8-15 
JAR,Volume 2 Nomor 2 Agustus 2019

$p$ ISSN 2615-417X

Coggon, et.al. 1996. Epidemiologi Bagi Pemula. Penerbit Buku Kedokteran

Dinas Pertanian. 2016. Pidie Jaya Dalam Angka. Pidie Jaya

Direktorat Pengelolaan Air. 2009. Pedoman Umum Sekolah Lapang Iklim. Direktorat Jenderal Pengelolaan Lahan dan Air, Departemen Pertanian.

http://pla.deptan.go.id/pdf/11_PED UM_SL_IKLIM.pdf. (Diakses 26 Agustus 2013)

Edi. 2013. Penggunaan Sistem Informasi Geografis (SIG) Citra Satelit Modis - Terra Dalam

Perencanaan

Produktifitas Padi di Provinsi Sumatra Utara. Perencanaan Pembangunan Wilayah dan Perdesaan USU. (Online), http://www.academia.Edu / 4564445/ Pemantauan Produktifitas Padi di Sumatera Utara dengan Citra Satelit Terra Modis. Di akses tanggal 28 Maret 2015.

Erawati, D. 2007, Aplikasi Sistem Informasi Geografis Untuk Pembuatan Peta Pariwisata Kabupaten Kulonprogo Dengan Visual Basic, Tugas Akhir, Yogyakarta : Fakultas Geografi, Universitas Gadjah Mada.

Güting, R. H. 1994. An introduction to spatial database systems, The VLDB Journal-The International Journal on Very Large Data Bases. Springer-Verlag New York, Inc., 3(4), hal. 357- 399.

Hidayat. T. 2011. Analisis Perubahan Musim Dan Penyusunan Musim Taman Tanaman Padi Berdasarkan Data Curah Hujan di Kabupaten Aceh Besar. Jurnal Agrista Vol.15 No. 3.Hal.87-93. (Online), www.iiste.org /Journals/ index.Php / JEES / ... / 17680.di akses pada tanggal 27 maret 2015

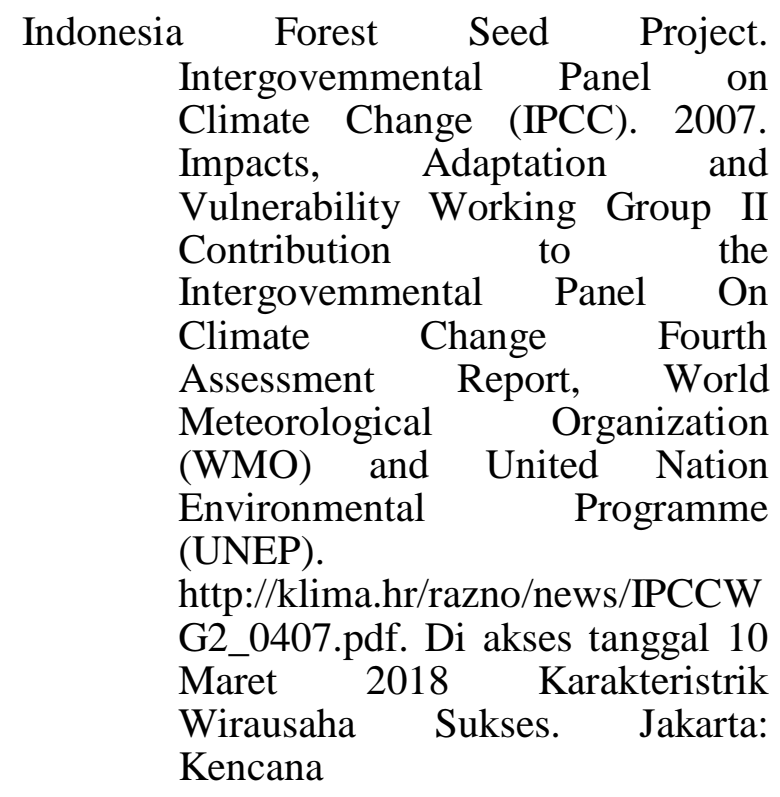

Kartasapoetra, A.G., 2006, Klimatologi: Pengaruh Iklim terhadap Tanah dan Tanaman. Jakarta: Bumi Aksara.

Kementerian Lingkungan Hidup. (2004). Perubahan iklim global. Diakses pada 27 Juli 2014, dari: http:/climatechange.menlh.go.id.

Lakitan, B. 2005. Dasar-Dasar Klimatologi. Cetakan Ke-2. Raja Grafindo Persada. Jakarta

Lembaga Ketahanan Nasional. 2013. Meningkatkan produktifitas pertanian guna mewujudkan Ketahanan Pangan dalam rangka ketahanan nasional.(online), Jurnal Kajian Lemhannas www.lemhannas.go.id / portal/...jurnal\% 20 edisi \% 2015_materi \% 202.pdf. Diakses tanggal 29 maret 2015.

Leonheart, 2010, Suhu Udara. (Internet) (di akses 12 April 2017).

Lillesand, TM \& Kiefer, R.W. 1979.Penginderaan Jauh dan Interpretasi Citra. Cetakan ke I. Gadjah Mada Press. Yogyakarta.

Lindgren D.T. 1985. Land Use Planning and Remote Sensing, Martinus Nijhoff 
Liu,T., D. Mao,S. Zhang, C. Xu, Y. Xing. 2009. Fine mapping SPP1, a QTL controlling the number of spikelets per panicle, to a $\mathrm{BAC}$ clone in rice (Oryza sativa). Theoretical and Applied Genetics 118 : 1509-1517

Marpaung, S., Satiadi, D.,Adikusumah, N.,Subarna, D., Suaydhi., Visa, J., dan Kusnandar, D. 2011. Kajian dan Sosialisasi Perubahan Iklim serta Antisipasi Dampaknya. http://www.ebookbrowse.com. [28/11/2011].

Miyan. M.A, 2014. Droughts in Asian lest developed countries: vulnerability and sustainability. Jurnal Elsevier \& jurnal weater and climate extreme

(Online):p.l.http://www.sciendirect .com/science/article/pii/S22120947 14000632.diakses tanggal 11 Desember 2014

Mostafa K. Mosleh K, M., Hassan, K Q., 2014.Development of a Remote Sensing-Based -Boro \| Rice Mapping System. Remote Sens 6, 1938-1953

Natawidjaja, R.S., Supyandi, D., Tulloh, C., Tridakusumah, A.C., Calford, E.M., dan Ford, M., 2009. Climate Change, Food Security and Income Distribution: Adaptations of Small Rice Farmers.Crawford School of Economics and Government at The Australian National University, Canberra.

Prasetyo, Y dan Arif, L.N. 2006. Analisis Tata Guna Lahan Kawasan Waduk Kedungombo Menggunakan Citra Satelit Lansat Tahun 1998 dan 2002.Jurnal Program Studi Teknik Geodesi Universitas Dipenogoro. Jawa Tengah.

Prawirowardoyo, S., 1996, Meteorologi, Bandung: Institut Teknologi Bandung.

Prospere, K., McLaren, K., Wilson, B., 2014. Plant Species
Discrimination in a Tropical Wetland Using In Situ Hyperspectral Data. Remote Sensing Vol6 8494-8523 (open access)Publishers, Doldrecht.

Rahmi, J. 2009. Hubungan Kerapatan Tajuk Dan Penggunaan Lahan Berdasarkan Analisis Citra Satelit Dan Sistem Informasi Geografis Di Taman Nasional Gunung Leuser (Studi Kasus Kawasan Hutan Resort Tangkahan, Cinta Raja, Sei Lepan dan Kawasan Ekosistem Leuser (KEL). (Online), http://

repository.usu.ac.id/bitstream/hand le/123456789/7637/09E02718.pdf; jsessionid=09DA29959B192B89D 6DBC61841D859B1? sequence $=1$. Di akses pada tanggal 27 Maret 2015

Ratnaningayu. 2009. Bagaimana Petani dan Nelayan menghadapi Dampak Perubahan Iklim. Sarasehan iklim. Nopember 2009. Pelangi Indonesia. Jakarta.

Ren. P. Z. and Hsing. T.. 2003. Internet GIS : Distributed Geographic Information Service for the Internet and Wireless Networks, John Wiley \& Sons, Inc, New Jersey,USA.

Ritchie, 1972. Pathogenesis of Virulent. ND in Chickens, Journal of Veterinary Medical Assosiation. 161: 169179.

Schmid, F. H dan Ferguson, J. H. A. 1951. Rainfall Types Based On Wet and Dry Period Rations for Indonesia With Western New Guinea. Jakarta: Kementrian Perhubungan Meteorologi dan Geofisika.

Short, N.M. 1982. The Landsat Tutorial Workbook. NASA. New York.

Sitorus, J., Purwandari., Luwin, E. D., Rina, W., dan Suharno. 2006. Kajian Model Deteksi Perubahan Penutupan Lahan Menggunakan Data. Inderaja Universitas 
Sumatera Utara untuk Aplikasi Perubahan Lahan Sawah. Bidang Pengembangan Pemanfaatan Inderaja Pusbangja Lapan.

Solihin, A., dan Sukartini, N.M. (2013). Respon Petani terhadap perkembangan teknologi dan perubahan iklim: Studi kasus di Desa Gadungan, Tabanan, Bali. Jurnal Ekonomi Kuantitatif Terapan. Vol. 6, hlm. 128-139.

Subarjo. M. 2001. Buku Ajar Meteorologi dan Klimatologi Universitas Lampung Bandar. Lampung

Suberjo, (2009). adaptasi pertanian dalam pemanasan global. Dosen Fakultas Pertanian UGM Yogyakarta dan Mahasiswa Doktoral The University of Tokyo. Diakses pada 12 Agustus 2014, dari: http://subejo.staff.ugm.ac.id/?p=10 $\underline{8}$.

Sulistyo, Bambang. 2004. Penginderaan Jauh Digital.Indonesia. Jakarta.

Surono. 2001. Simposium Free Radical in Diabetes and Their Sulphonylureas diselenggarakan PERKENI, Jakarta Hotel Hilton 24 Maret 2001.

http://www.Indomedia.com/intisari /1997/Feb/diabet2.htm.

November 2015.

Suryana, Yuyus dan Kartib Bayu. 2001. Kewirausahaan Pendekatan

Sutanto. 1986. Pengideraan Jauh Jilid I. Yogyakarta: Gadjah Mada University Press

Sutarja, 2013. Kajian Akademis Master Plan Risiko Bencana Kekeringan. Seminar Nasional. Denpasar : Pusat Studi Bencana, Universitas Udayana

Tambunan. T.H 2011. Industrialisasi di Negara sedang Berkembang Ksus Indonesia. Jakarta. Ghalia Indonesia.
Wahyunto. 2007. Peranan Citra Satelit Dalam Penentuan Potensi Lahan. http://www.litbang.deptan.go.id/w arta-ip/pdf-file/wahyunto-13.html. [6 Maret 2011]

Yasin, I., M. Ma' shum, Y. Abawi, dan

Hadiawati. 2002. Penggunaan Flowcast untuk Menentukan Awal Musim Hujan dan Menyusun Strategi Tanam di Lahan Sawah Tadah Hujan di Pulau Lombok. Pros. Seminar Nasional Peningkatan Pendapatan Petani Melalui Penerapan Teknologi Tepat Guna. BPTP NTB.

Yaslinus, 2009. Penginderaan Jauh. http://www.oocities.org. diunduh pada Selasa, 04 September 2012

Zaibio. 2014. Musim Tanam Tumpang Sari. (Online), https: // zaifbio.wordpress. Com /tag/musim-tanam/. Di akses tanggal 30 maret 2015 